\title{
The Müritzeum in Waren (Müritz): natural history museum and modern nature discovery centre
}

\author{
Mathias Küster ${ }^{1,2}$ \\ ${ }^{1}$ Institute of Geography and Geology, University of Greifswald, Friedrich-Ludwig-Jahn-Straße 16, \\ 17487 Greifswald, Germany \\ ${ }^{2}$ Department for Exhibition and Natural History Collections, Müritzeum gGmbH, 17192 Waren (Müritz), Germany
}

Correspondence: Mathias Küster (m.kuester@mueritzeum.de)

Relevant dates: $\quad$ Published: 15 August 2019

How to cite: $\quad$ Küster, M.: The Müritzeum in Waren (Müritz): natural history museum and modern nature discovery centre, DEUQUA Spec. Pub., 2, 77-81, https://doi.org/10.5194/deuquasp-2-77-2019, 2019.

Abstract:

The Müritzeum is a nature discovery centre and a museum in the heart of the Mecklenburg Lake District. It is the first natural history museum in Mecklenburg-Vorpommern, with natural history collections that are over 150 years old, and are still growing today. The collections contain about 290000 specimens from the fields of botany, zoology and geology. An extensive library and an archive are also part of the museum. Collecting, preserving and researching natural history are our main spheres of activity. The exhibition in the Müritzeum offers the visitor a comprehensive insight into the development of the nature and landscape of northeastern Germany and of Mecklenburg-Vorpommern and the Lake Müritz region in particular. The largest aquarium for indigenous freshwater species in Germany enables visitors to imagine themselves in the underwater world of the Mecklenburg Lake District.

\section{History of the museum - an outline}

The museum of natural history in Waren (Müritz) has existed for over 150 years. In the 18th and 19th centuries there were extensive natural history collections in private cabinets and at universities of varying sizes. However, these were not accessible to the public. In 1866, Freiherr Hermann von Maltzan (1843-1891) founded the "von Maltzan'sche Naturhistorische Museum für Mecklenburg" (the von Maltzan's museum of natural history for Mecklenburg, also known as the "Maltzaneum"). It was the first official museum of natural history in the then Grand Duchy of Mecklenburg-Schwerin (Seemann, 2018a). The founder's aim was to provide natural scientists a platform for professional exchange and to give the public the opportunity to find out about their local environment. The natural history collections laid the foundation for our museum. In the founding years and beyond, Hermann von Maltzan and the first curator and director of the museum, Carl Struck, were very active members of the "Verein der Freunde der Naturgeschichte in Mecklenburg" (Association of friends of natural history in Mecklenburg). In this way, many contacts were established with collectors, thus the natural history collections grew significantly.

By buying and selling real estate, the collection was housed in several locations in Waren (Müritz) in the years from 1884 to 1929 . After that it arrived in its present location, in the present-day House of Collections, which was an old public school in 1929 (Fig. 1), through the support of the association "Vereinigung für Heimatschutz" (an organisation for regional conservation). In the coming years the museum's curatorial teams, who were members of the association, worked on a voluntary basis. 


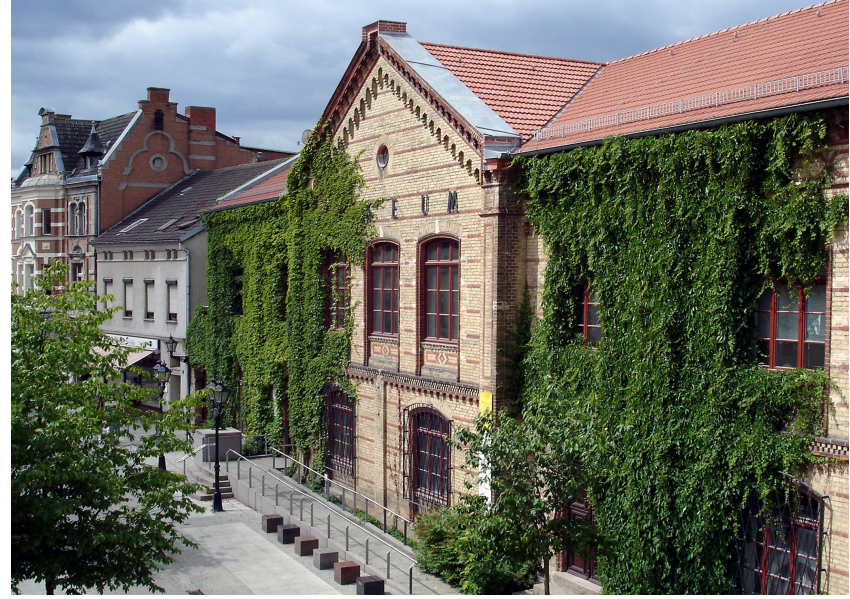

Figure 1. The historical building that is today the "House of Collections" (Photo: Müritzeum).

During the Second World War the museum and the collections were largely spared from destruction, however, during the last days of the war several specimens of the bird collection were stored in the Sophienhof castle near Waren (Müritz). The castle and nearly all specimens were destroyed by arson (Seemann, 2018a). In the post-war years, the insect collection was considerably expanded and reorganised. A specialist library, among other things, was set up by Carl Hainmüller (1875-1956).

In 1957 the Maltzaneum was united with the local history museum under the name "Müritz-Museum". The exhibition was reorganised, and the focus was put on educational and nature conservation tasks. In 1973, the Museum got the status of a special museum for state culture, nature conservation and the environment. After excluding the prehistoric and historic collections, the renovation of the museum building between the years 1982 and 1991, and its reorganisation, the museum got its mission statement, making it the "Natural History Museum for the State of MecklenburgVorpommern" (Seemann, 2018a).

In 1982 the "Müritz-Aquarium" was founded as a part of the Müritz-Museum. The construction of a large aquarium with native freshwater fish species was an absolute novelty in northeastern Germany. A total of $25000 \mathrm{~L}$ of water were distributed in 16 aquariums, the largest of which contained $8000 \mathrm{~L}$ of water. More than 20 native species of fish were presented in the tanks.

In 2007, a project of remodelling, lasting several years, ended, accompanied by renovation work on the historic museum building, the House of Collections, and the construction of a new modern exhibition building, the "House of 1000 Lakes" (Fig. 2). Since the foundation of the Müritzeum $\mathrm{gGmbH}$ in 2007, visitors have been able to gain a lasting insight into nature from a modern exhibition, the largest aquarium for local freshwater species and the museum garden.

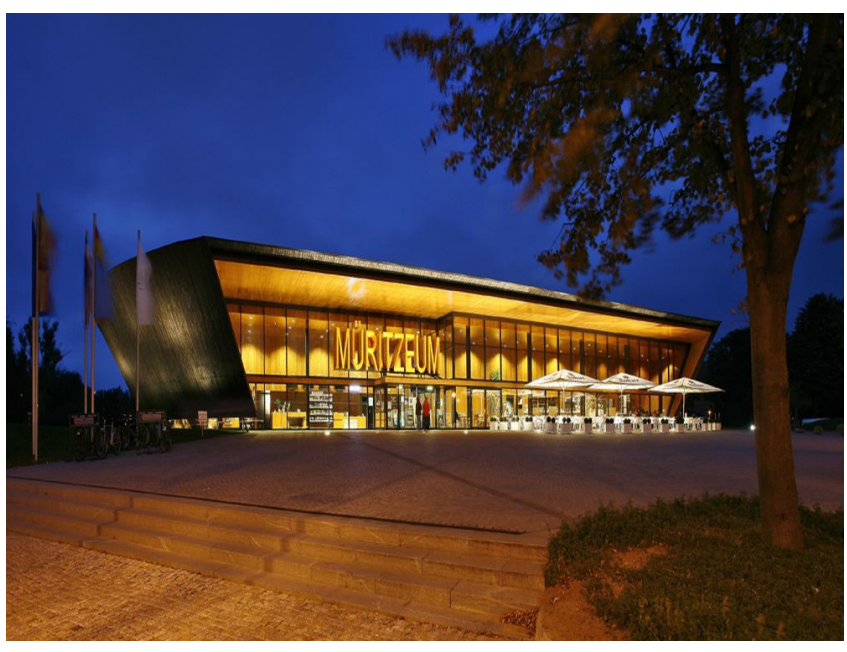

Figure 2. The new exhibition building "House of 1000 Lakes" (Photo: Mirko Runge).

\section{Natural history collections}

Over a period of 150 years approx. 290000 natural historical specimens have been collected. In one specimen several individuals of one species can be combined, thus there are several million natural history objects. The specimens are housed either in depots or in the exhibition. The collections consist of botanical, zoological and geological specimens. These collections are taken mainly from the area of MecklenburgVorpommern but, with regard to the entire collection of individual collectors, some specimens from all over the world have been added to the collections.

In addition, over the years an extensive archive, with reference to the collections or the collectors, has been created. This includes field descriptions, collection catalogues, correspondence and maps. A recent census showed a stock of over 80000 photos. The library holds over 16000 books, 12000 journals and 1200 special editions. Content from the fields of botany, zoology, geology, geography, forestry and hunting sciences, agriculture, landscape history and nature conservation is presented. A total of 1200 books are over 100 years old. The oldest book is from 1588 .

The most extensive collection of the natural history collections is that of the insects (Fig. 3). Today it contains roughly 175000 specimens. The collection of small butterflies and moths is especially worth mentioning here, with $7500 \mathrm{spec}-$ imens it is the largest collection of its kind in MecklenburgVorpommern. The coleopteran beetle collection, with 42000 specimens, is also of great importance. The cerambycid collection with 6317 specimens from 505 species and 61 subspecies is the largest in Mecklenburg-Vorpommern (Seemann, 2018a). The most recent additions to the collection were in 2017 (Schemschat, 2017).

The bird collection includes 3030 mounted and prepared birds and bird bodies, 4115 clutches with more than 11000 


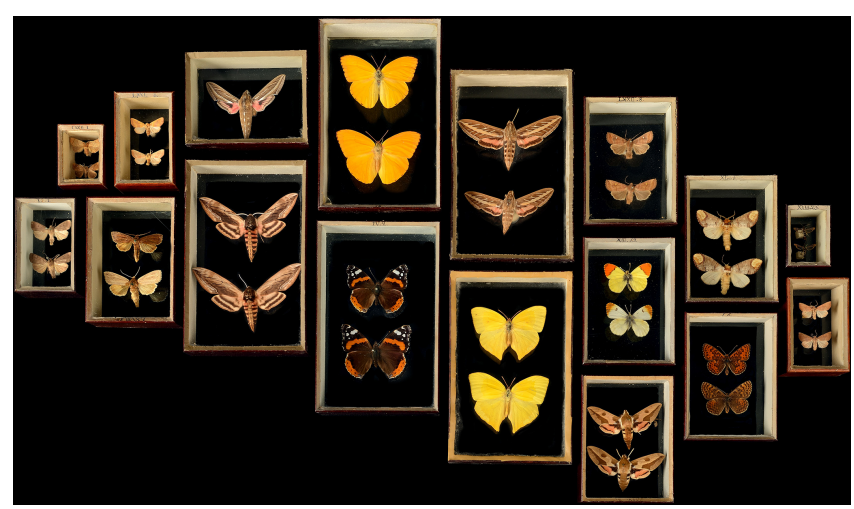

Figure 3. Insects form a large part of the natural history collection (Photo: Sebastian Köpcke and Volker Weinhold).

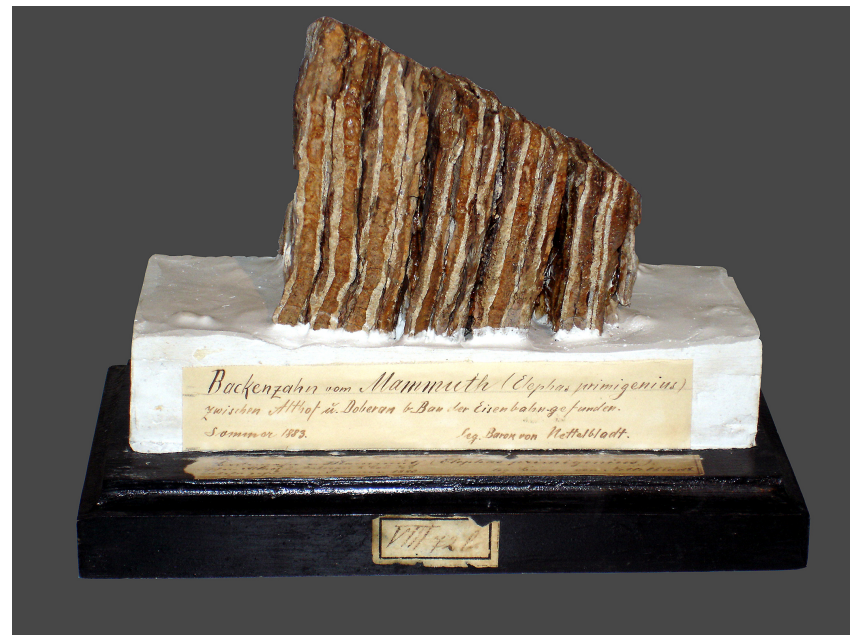

Figure 4. Subfossil record: historical specimen of a Mammoth molar tooth found in 1883 (Photo: Müritzeum).

eggs, 696 plucked birds, and around 300 skeletons (Seemann, 2018a). Nearly all breeding native bird species and birds of passage or vagrant species have been collected (Seemann and Seemann, 2011). For several years the Müritzeum has been a partner in the joint cause of the state project "Research into causes of death" together with the State Office for the Environment, Nature Conservation and Geology of MecklenburgVorpommern and the Leibniz Institute for Zoo and Wildlife Research in Berlin. Investigated mortal finds, especially of white-tailed eagles and ospreys, are documented and included in the collection (Seemann and Seemann, 2011).

Other zoological collections are the mammal collection (including subfossil records, Fig. 4); the mollusc collection; and small collections of amphibians, reptiles, fish, crabs, leeches, and spiders. Nearly 35000 plants, comprising flowering plants, ferns, mosses, algae and fungi, are also part of the biological collections.

About 25000 specimens, including rocks, minerals and fossils belong to the geological collection. Above all, Nordic debris ("Geschiebe") from Scandinavia, the Baltic Sea region and Mecklenburg-Vorpommern are of great importance for the "ice age region" of northern Germany. The latest addition was a collection of Nordic debris in 2016 (Günther and Küster, 2018). Currently, a transfer to the museum is being prepared for a collection with numerous specimens, including holotypes from the Cambrian.

In addition to the preservation of the collections and the planning and realisation of exhibitions, research is carried out on the natural history collections by the scientific staff of the museum, external scientists and volunteers. Among other things, this research deals with natural history questions about specimens; Glacial, Holocene, and recent species distribution and species change; and studies of collectors and collection history (see Ukkonen et al., 2011; Küster and Günther, 2016; Seemann, 2018b, c; Thiele et al., 2018).

\section{Exhibition}

The permanent exhibition in the Müritzeum gives visitors a comprehensive insight into the nature and the development of the landscape of northeastern Germany. A wide range of interaction and exploration facilities are offered to the visitors. Especially in the House of the 1000 Lakes one can enjoy the bird exhibits, the forest, a journey through time from the Ice Age to the present, and the formation and the development of Lake Müritz with its underwater world. In the bird exhibition space, the visitor is shown the diversity of birdlife by, for example, listening to bird songs and calls in the concert hall. Interesting facts about bird migration and bird research are also shared. The newly designed "high-tech balloon room" realistically simulates a crossing over the Mecklenburg Lake District (Küster, 2018a).

The life of trees can be traced from the root to the treetop in the forest room. A 1000-year-old oak tree tells the history of the forest over centuries. The "forest at night" room offers the possibility of listening to the sound of the forest at night, a single button press and you are face-to-face with the animals. The new exhibition space for the UNESCO World Natural Heritage listed ancient beech forests of Germany explains the importance of these rare and unique habitats (Fig. 5, Küster, 2018a).

The largest aquarium for indigenous freshwater species in Germany, presenting the underwater world of the Mecklenburg Lake District, always causes astonishment. This $100000 \mathrm{~L}$ fish tank that extends over two levels, with hundreds of whitefish moving in an unbroken circle attracting the visitors' attention (Fig. 6). In 26 "near-natural" large and small fish tanks, one can discover about 50 different types of fish, in addition to crabs, terrapins, mussels, snails and aquatic plants.

The House of Collections not only presents the collections of natural history in magazines, the library and the archive but also a permanent exhibition about collecting, preserv- 


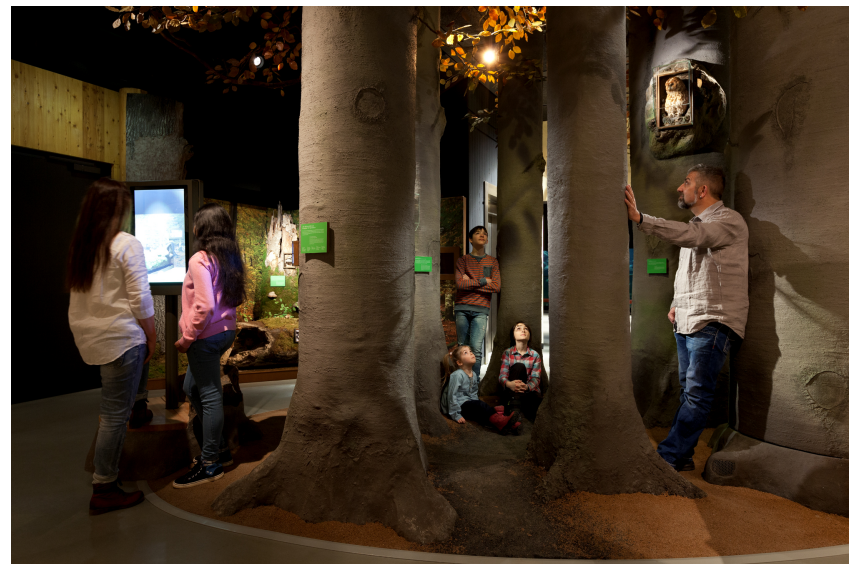

Figure 5. New exhibition - the UNESCO World Natural Heritage listed ancient beech forests of Germany (Photo: Mirko Runge).

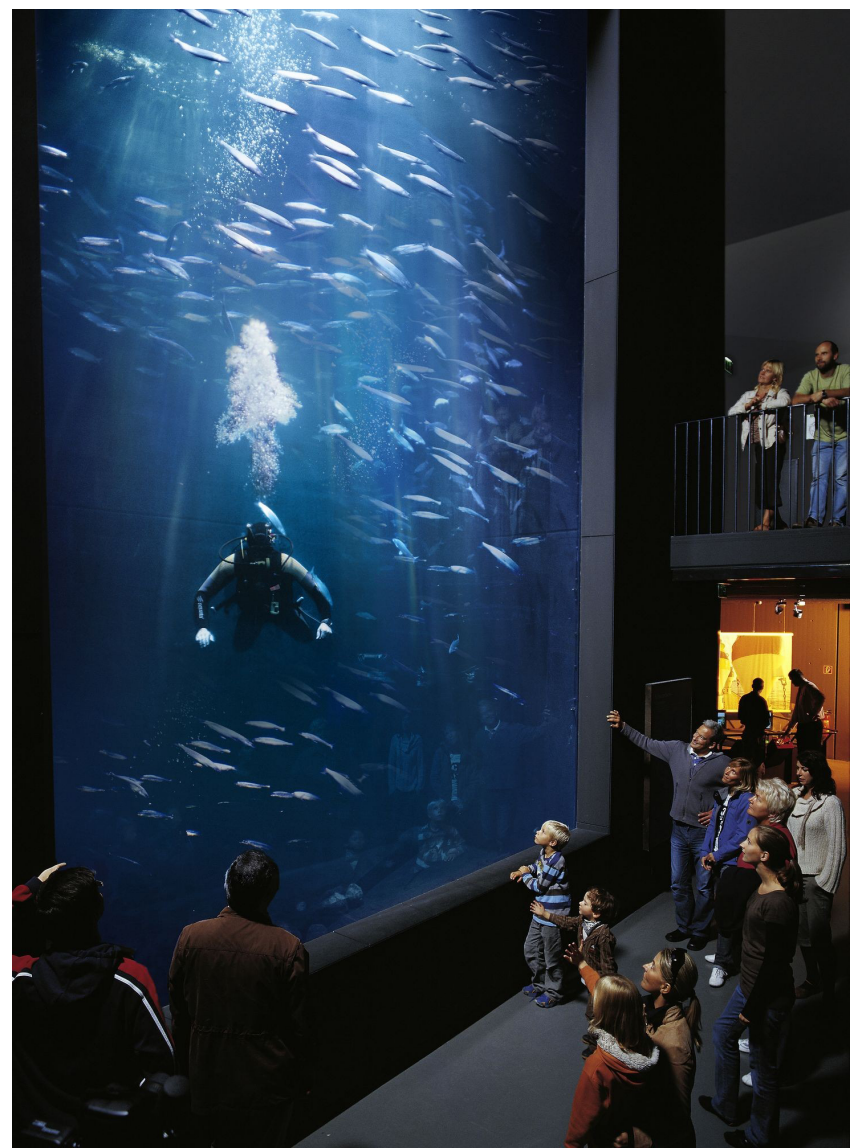

Figure 6. The $100000 \mathrm{~L}$ fish tank containing 300 whitefish is a highlight of the aquarium area of the museum (Photo: Werk3/Andreas Duerst).

ing and researching natural history as well as special exhibitions about environmental and historical topics. Around 1500 specimens of the natural history collection can be admired in the entirety of the Müritzeum.
A circular path leads you around the Herrensee in the museum garden. As a natural body of water it is the habitat of many species of breeding birds. An artificial island built in 2018 helps secure the population of a colony of black-headed gulls that has been breeding on the site for 50 years (Küster, 2018b). Large erratic boulders protected as geotops, as well as a boulder garden, give evidence of the geological past of the region and the origin of the rocks (Günther, 2010).

Data availability. All data relevant for this contribution are presented within the article itself.

Competing interests. The author declares that there is no conflict of interest.

Acknowledgements. I would like to thank Ralf Scheibe (Greifswald) for the review. We acknowledge support for the article processing charge from the DFG (no. 393148499) and the Open Access Publication Fund of the University of Greifswald.

Financial support. This research has been supported by the DFG (German Research Foundation, grant no. 393148499) and the Open Access Publication Fund of the University of Greifswald.

\section{References}

Günther, A.: Die Geologische Sammlung im Müritzeum in Waren (Müritz), Neubrandenburger Geologische Beiträge, 10, 131-144, 2010.

Günther, A. and Küster, M.: Gesteinssammlungen aus dem Strelitzer Land im Müritzeum, in: Zur Geologie und Landschaft des Strelitzer Landes, edited by: Naturschutzbund Deutschland e.V., Regionalverband Mecklenburg Strelitz, Labus - Sonderheft 25, Phönix Multimedia, Neustrelitz, Germany, 148-154, 2018.

Küster, M.: Neue Impulse in der Dauerausstellung des Müritzeums 2018, Mitteilungen des Museumsverbandes MecklenburgVorpommern, 27. Jahrgang, 48-49, 2018a.

Küster, M.: Eine neue Brutinsel im Herrensee - aktiver Vogelschutz im Müritzeum, Mitteilungen des Museumsverbandes Mecklenburg-Vorpommern, 27. Jahrgang, 46-47, 2018b.

Küster, M. and Günther, A.: Aspekte zum Ichnofossil Ophiomorpha nodosa anhand eines norddeutschen Geschiebes, Geschiebekunde aktuell, 32, 113-119, 2016.

Schemschat, L.: Neues über die Käfersammlungen des Müritzeums in Waren (Müritz) (Coleoptera: Cerambycidae), Virgo, 19. Jahrgang, Heft 1, 33-35, 2017.

Seemann, F. and Seemann R.: Katalog der Vogelsammlung des Müritzeums, Präparate, Eier, Skelette, Rupfungen, Veröffentlichungen der Naturhistorischen Landessammlungen für Mecklenburg-Vorpommern im Müritzeum, 18, 270 pp., 2011.

Seemann, R.: Waren: Müritzeum with the Natural History Collections for the State of Mecklenburg-Vorpommern, in: Zoological Collections of Germany - The Animal Kingdom in its Amaz- 
ing Plenty at Museums and Universities, edited by: Beck, L. A., Springer Nature, Cham, Switzerland, 647-658, 2018a.

Seemann, R.: Fundstücke - Seltene Druckwerke im Bestand der Naturhistorischen Landessammlungen für MecklenburgVorpommern, Archiv Natur und Landeskunde MecklenburgVorpommern, 55, 54-69, 2018b.

Seemann, R.: "Zwar weiß ich viel, doch will ich alles wissen..." - Die Geschichte(n) hinter den Sammlungen, Mitteilungen des Museumsverbandes Mecklenburg-Vorpommern, 27. Jahrgang, 16-20, 2018c.

Thiele, V., Blumrich, B., Gottelt-Trabandt, C., Schuhmacher, S., Eisenbarth, A., Berlin, A., Deutschmann, U., Tabbert, H., Seemann, R., and Steinhäuser, U., in cooperation with: Büsch, S., Duvekot, D., Schlomm, M., and Höfs, C.: Verbreitungsatlas der Makrolepidopteren Mecklenburg-Vorpommerns, Allgemeiner Teil und Artengruppen der Blutströpfchen, Schwärmer, Bären und Spinnenartigen, edited by: Landesamt für Umwelt, Naturschutz und Geologie Mecklenburg-Vorpommern and biota - Institut für ökologische Forschung und Planung $\mathrm{GmbH}$, Steffen Media GmbH, Friedland, Berlin, Germany, 352 pp., 2018.
Ukkonen, P., Aaris-Sørensen, K., Arppe, L., Clark, P. U., Daugnor, L., Lister, A. M., Lõugas, L., Seppä, H., Sommer, R. S., Stuart, A. J., Wojtal, P., and Zupin, I.: Woolly mammoth (Mammuthus primigenius Blum.) and its environment in northern Europe during the last glaciation, Quaternary Sci. Rev., 30, 693-712, 2011. 